\title{
Identifying novel genetic alterations in pediatric acute lymphoblastic leukemia based on copy number analysis
}

\author{
Jéssica Almeida Batista-Gomes ${ }^{1}$ (D), Fernando Augusto Rodrigues Mello $\mathrm{Jr}^{1}$, Edivaldo Herculano Corrêa de Oliveira ${ }^{2}$, \\ Michel Platini Caldas de Souza², Alayde Vieira Wanderley³, Laudreisa da Costa Pantoja3, \\ Ney Pereira Carneiro dos Santos ${ }^{1}$, Bruna Cláudia Meireles Khayat ${ }^{1}$ and André Salim Khayat ${ }^{1 *}$
}

\begin{abstract}
Copy number variations (CNVs) analysis may reveal molecular biomarkers and provide information on the pathogenesis of acute lymphoblastic leukemia (ALL). We investigated the gene copy number in childhood ALL by microarray and select three new recurrent CNVs to evaluate by real-time PCR assay: DMBT1, KIAA0125 and PRDM16 were selected due to high frequency of CNVs in ALL samples and based on their potential biological functions in carcinogenesis described in the literature. DBMT1 deletion was associated with patients with chromosomal translocations and is a potential tumor suppressor; KIAA0125 and PRDM16 may act as an oncogene despite having a paradoxical behavior in carcinogenesis. This study reinforces that microarrays/aCGH is it is a powerful tool for detection of genomic aberrations, which may be used in the risk stratification.
\end{abstract}

Keywords: ALL (acute lymphoblastic leukemia) childhood leukemia, DMBT1, KIAA0125, PRDM16, Copy number variations

\section{Introduction}

Acute lymphoblastic leukemia (ALL) is the most common cancer in children [1]. Leukemia represents the ninth most common cancer in Brazil and the fifth most frequent in the north region [2]. Advances in cytogenetics and molecular cytogenetics has allowed the identification of genetic aberrations in more than $80 \%$ of ALL cases [3]. Establishing genetic background in ALL patients is important for the diagnosis, risk classification and therapeutic interventions [3]. However, some patients do not have an established chromosomal aberration, which complicates the risk classification.

Recent analysis has shown that copy number variations (CNVs) are common in ALL and leukemia in general, especially in genes involved in transcription, cell cycle regulation and B-cell differentiation, (e.g., $C D K N 2 A / B$,

\footnotetext{
* Correspondence: khayatas@gmail.com

${ }^{1}$ Oncology Research Center, Federal University of Pará, Belém, Brazil

Full list of author information is available at the end of the article
}

IKZF1, ETV6, EBF1, PAX5, BTG1 and PAR1) [4]. Additional CNVs could be helpful to refine ALL prognostic. The prognostic effect of CNVs depends on the other factors, such as the presence of additional molecular or cytogenetic aberrations; this situation reinforces the need to analyze these combined alterations [5].

The aim of this report is to assess and evaluate CNVs identified by aCGH from a cohort of Brazilian children with ALL. Three new recurrent CNVs were further evaluated by qPCR. We highlight that DMBT1, KIAA0125 and PRDM16 were chosen due to high frequency of aberrations in ALL samples and based on their biological functions as well the data present in the literature.

\section{Methods \\ Patients}

A total of 16 ALL pediatric patients ( $5 \pm 3$ years) treated at Octávio Lobo Children's Cancer Hospital were selected for aCGH analysis. Additional 84 ALL pediatric 
samples were used as validation group in copy number qPCR assay. These patients were classified by immunophenotyping and morphology. Gene fusions were investigated by reverse transcription polymerase chain reaction (RTq-PCR) (Tables 1 and 2). The samples were collected before cancer treatment between 2017 and 2019.

The age at diagnosis and white blood cell (WBC) count were the criteria for assigning prognostic risk of ALL, according to the National Cancer Institute (NCI): 1) high risk, WBC count greater than $50 \times 10^{9}$ cells $/ \mu \mathrm{L}$, age 1 year or less, or age 10 years or more; and 2) standard risk, WBC count $50 \times 10^{9}$ cells $/ \mu \mathrm{L}$ or less, or between 1 and 10 years of age. The patients with $B C R-A B L 1$ or $M L L-$ $A F 4$ also were assigned to the NCI high risk group. Written consent forms were obtained from all parents of patients. This study was approved by hospital ethics committee (CAAE: 00905812.1.0000.00.18).

\section{Array comparative genomic hybridization}

Genomic DNA was extracted from peripheral blood by Pure Link Genomic DNA Mini Kit (Invitrogen, California, USA). aCGH was performed using Agilent 4x180k CGH + SNP microarray (Santa Clara, USA). After DNA extraction, a restriction enzyme digestion step and labeling with fluorochrome cyanine 5 were performed using random primers and exo-Klenow fragment DNA polymerase. DNA control was labeled with fluorochrome cyanine 3 . DNA samples from the patient and control were combined and hybridized on the microarray. Data were analyzed using the software Agilent's CytoGenomics v5.0.

Table 1 Characteristics of pediatric patients with ALL included in the study

\begin{tabular}{lll}
\hline Characteristic & $\mathrm{aCGH}(n=16)$ & $\mathrm{qPCR}(n=84)$ \\
\hline Male: female & $08: 08$ & $49: 35$ \\
Median age (y) & 6.5 & 7.4 \\
Median WBC count $\left(\times 10^{9} / \mathrm{L}\right)$ & 73 & 69.4 \\
Immunophenotype & & \\
B & 15 & 80 \\
T & 1 & 4 \\
Chromosomal alteration & & \\
TCF3-PBX1 (n) & 6 & 15 \\
BCR-ABL1 (n) & 1 & 9 \\
MLL-AF4 (n) & & 5 \\
ETV6-RUNX1 (n) & & 7 \\
SIL-TALI (n) & & 3 \\
NCI risk & & 30 \\
High (n) & 7 & 54 \\
Standard (n) & 9 & \\
\hline
\end{tabular}

Table 2 Nucleotide sequence of RTq-PCR primers

\begin{tabular}{lllll}
\hline Genes & Primers $\left(5^{\prime}\right.$-3') & Size (bp) & Position & Exons \\
\hline TCF3 & CTACTCCCCGGATCACTCAA & 20 & $1086-1105$ & 13 \\
PBX1 & AGGCTTCATTCTGTGGCAGT & 20 & $3893-3912$ & 2 \\
MLL & CGCCCAAGTATCCCTGTAAA & 20 & $4071-4090$ & 8 \\
AF4 & GAGCATGGATGACGTCCTT & 20 & $1546-1565$ & 8 \\
BCR & TCGCAGAACTCGCAACAGT & 19 & $1707-1725$ & 1 \\
ABL & ACACCATTCCCCATTGTGAT & 20 & $284-303$ & 3 \\
ETV6 & TCTCTCATCGGGAAGACCTG & 20 & $1191-1210$ & 5 \\
RUNX1 & TGCGGTAGCATTTCTCAGC & 19 & $619-637$ & 5 \\
SIL & TCCTACCCTGCAAACAGACC & 20 & $73-92$ & 1 \\
TAL1 & AGGCGGAGGATCTCATTCTT & 20 & $1250-1269$ & 4 \\
\hline
\end{tabular}

\section{Real-time quantitative PCR}

TaqMan Copy Number Assay (Applied Biosystems, California, USA) was used to assess copy number for DMBT1, KIAA0125 and PRDM16. Briefly, $1 \mu \mathrm{L}$ of $10 \mathrm{ng}$ DNA was added to $5 \mu \mathrm{L}$ of TaqMan Universal Master Mix no UNG, with $0.5 \mu \mathrm{L}$ of each probe and $3 \mu \mathrm{L}$ of ultra-pure water. RNase P was used as a control. The amplification protocol consisted of: denaturation at $95^{\circ} \mathrm{C}$ for $10 \mathrm{~min}$, followed by 40 cycles of $95^{\circ} \mathrm{C}$ for $15 \mathrm{~s}$ and $60^{\circ} \mathrm{C}$ for $1 \mathrm{~min}$. Relative quantification was determined using the 7500 Real-time PCR system and all samples were analyzed in quadruplicate. After amplification, we imported the experiment results containing threshold-cycle values for the copy number and reference assay into the Copy Caller Software v2.0 for post-PCR data analysis as previously described [6].

\section{Statistical analysis}

Fisher's exact test was used to compare the distribution of aberrations between subgroups (high or standard risk; positive or negative for chromosomal translocation) and pathological features of the patients; Odds ratio (OR) with a 95\% confidence interval (CI) were also calculated through the statistical program BioEstat ${ }^{\oplus}$ v5.0 [7]. $p$ values less than 0.05 were considered significant.

\section{Results aCGH profiling identifies recurrent alterations}

aCGH date were available for all 16 cases, the average of copy number variations (CNVs) was 8.3 per sample. Gains were the most frequent event, the most frequently gained regions were on chromosomes 14 (q32.33) and 10 (q26.13), these regions include KIAA0125 (a lncRNA) and $D M B T 1$ genes, respectively. Frequent losses were identified on chromosome 7 (7p12.2) and 9 (p21.3), which includes $I K Z F 1$ and $C D K N 2 A / B$ genes, respectively.

Recurrent CNVs included gains of cytobands $14 \mathrm{q}$ (93.75\%), 2p (68.75\%), 17q (62.5\%), 9q (56.25\%), 10q 
(56.25\%), 19q (56.25\%), 22q (56.25\%), 1p (50\%), 7q (50\%), 8p (50\%) and 21q (50\%); losses involving 7p (62.5\%), 9p (56.25\%), 15q (47.75\%), 4q (37.5\%) and $12 \mathrm{q}$ (31.25\%). The list of recurrent CNVs found in at least two samples is provided in Table 3.

All patients have alteration in at least one of the main genes associated with ALL; ETV6, RUNX1, IKZF1, KMT2A (MLL) and BTG1 (Table 3.). The median of alterations in standard (SR) and high risk (HR) group were $56.6( \pm 15.4)$ and e $52.2( \pm 14.2)$, respectively. We confirmed the association of CDKN2A/B losses with positive cases for TCF3-PBX1 or BCR-ABL1 $(p<0.05)$. There was no statistically significant difference in the number of CNVs between patients with $(\mathrm{CT}+)$ or without (CT-) chromosomal translocation.

\section{CNV evaluation by real-time qPCR}

To validate aCGH results DMBT1, KIAA0125 and PRDM16 genes were analyzed by qPCR. Genes were chosen due to the high frequency of aberrations found in samples and based on their biological function (mainly transcriptional regulation) described in literature. It is noted that the CNV found in these genes are described here for the first time in leukemia, especially in ALL. The aberrations of the three selected genes identified from aCGH and qPCR were illustrated in Fig. 1.

The results of qPCR were compared between positive $(\mathrm{CT}+)$ or negative (CT-) for gene fusions subgroups.
DMBT1 deletion was observed in $74 \%$ of patients $(n=$ 62; $97.4 \%$ of CT + and 53\% of CT-); KIAA0125 amplification was detected in $59 \%$ of cases $(n=50 ; 95 \%$ of CT+ and $29 \%$ of CT-), these amplifications were more frequent in cases CT+; while PRDM16 was deleted in 50\% of patients $(n=42 ; 87 \% \mathrm{CT}$ - and $8 \% \mathrm{CT}+)$, amplifications were observed in $42 \%$ of samples, which only correspond to $\mathrm{CT}+$ cases (Fig. 2).

Curiously, 50\% (25/50) and 69\% (24/35) of KIAA0125 and PRDM16 amplifications, respectively, were highlevel amplifications (> 10 copies), however, classification of cases according to the level of amplification did not result in any significant association.

The frequency of aberrations in DMBT1, KIAA0125 and PRDM16 according to NCI risk group, gender, age and cytogenetic findings are show in Tables 4 and 5 Statistical analysis showed that DMBT1 deletion was more common in patients with $>1$ to $\leq 10$ years $(\mathrm{OR}=$ 3.38; $95 \% \mathrm{IC}=1.15-9.89$ ) and more common in NCI-SR cases $(\mathrm{OR}=0.198 ; 95 \% \mathrm{IC}=0.07-056)$. DMBT1 deletion also was associated with $\mathrm{CT}+$ samples $(\mathrm{OR}=33.2 ; 95 \%$ $\mathrm{IC}=4.19-263.55$ ) (Tables 4 and 5).

KIAA0125 amplification was associated with CT+ cases $(\mathrm{OR}=45.5 ; 95 \% \mathrm{IC}=9.54-217-16)$. PRDM16 gene deletion was associated with NCI-HR patients $(\mathrm{OR}=$ 91.4; $95 \%$ IC $=11.32-738.6)$ and $C T$ - cases $(\mathrm{OR}=0.01$; 95\% IC $=0.00-0.05$ ) (Tables 4 and 5), while amplification was related to $\mathrm{CT}+$ samples $(p$-value $=<0.001)$, data not shown in Tables 4 and 5).

Table 3 The most frequent copy number variations found in pediatric ALL by aCGH

\begin{tabular}{|c|c|c|c|c|}
\hline Frequency \% $(n=16)$ & Chromosome & Reference region & Variant type & Genes involved \\
\hline 94 & 14 & q32.33 & Amp & KIAA0125 \\
\hline 75 & 14 & q11.22 & Del & Several genes \\
\hline 62.5 & 7 & $7 p 12.2$ & Del & IKZF1 \\
\hline 56.25 & 9 & p21.3 & Del & CDKN2A/B,MTAP \\
\hline 56.25 & 10 & q26.13 & Amp & $D M B T 1^{a}$ \\
\hline 56.25 & 22 & q11.22 & Amp & MIR650, IGLL5 \\
\hline 50 & 15 & q11.1 & Del & HERC2P3 \\
\hline 50 & 1 & p36.32 & Amp & PRDM16 ${ }^{a}$ \\
\hline 50 & 19 & q13.32 & Amp & KLC3, ERCC2 \\
\hline 37.5 & 4 & q13.2-q13.3 & Del & UGT2B4 \\
\hline 31.25 & 12 & q21.33-q22 & Del & BTG1 \\
\hline 25 & 13 & q14.2 & Del & $R B 1$ \\
\hline 19 & 7 & p14.1 & Del & TRGC2, TARP \\
\hline 19 & 11 & $\mathrm{q} 23.3$ & Del & KMT2A \\
\hline 19 & 12 & $12 \mathrm{p} 13$ & Del & ETV6 \\
\hline 12.5 & 7 & p21.3-p15.2 & Del & Several genes \\
\hline 12.5 & 3 & q29 & Del & DLGI \\
\hline 6.25 & 21 & iAMP21 & Amp & RUNXI \\
\hline
\end{tabular}

${ }^{a}$ Alterations have never been described in literature for ALL. Amp amplification. Del deletion 


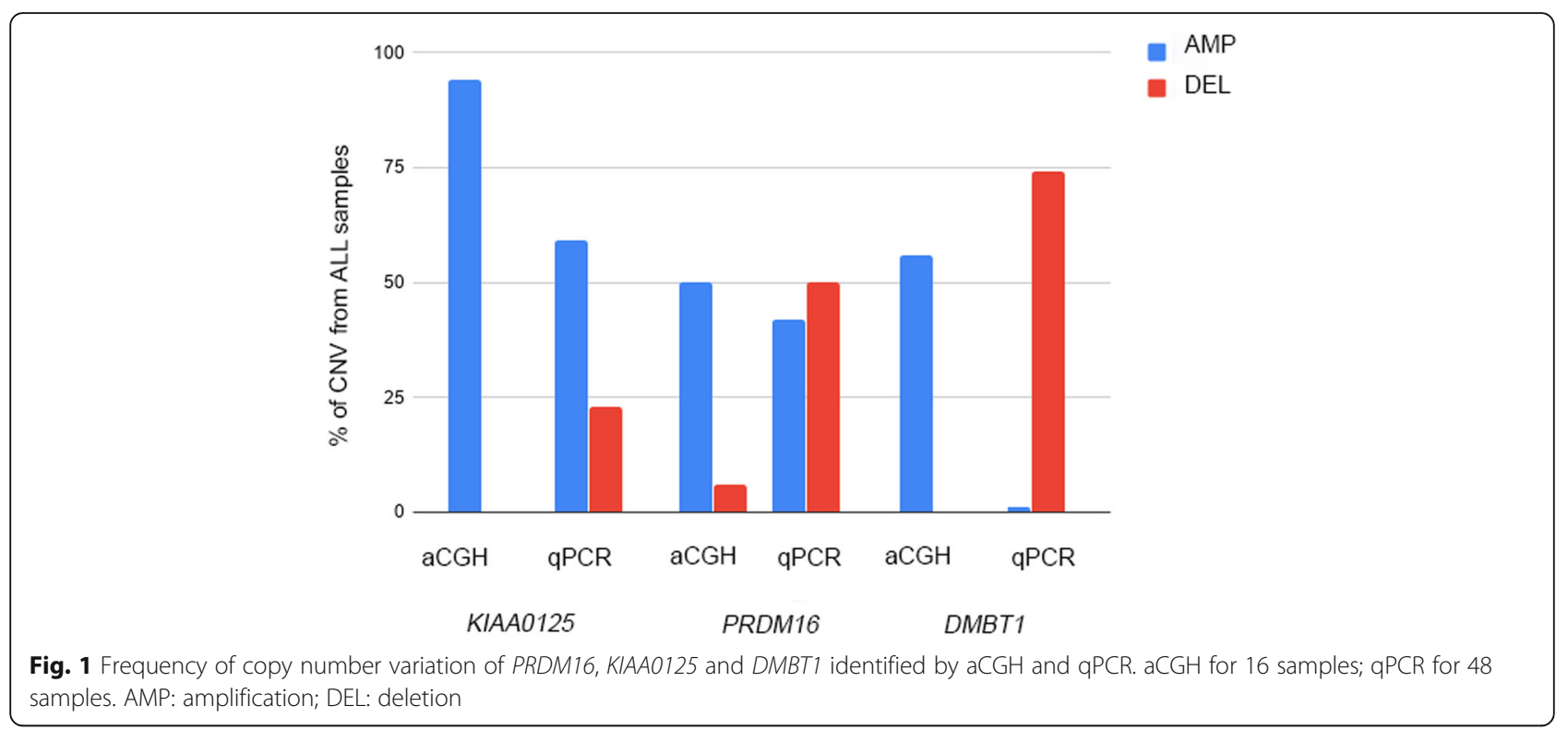

\section{Discussion}

All patients analyzed by aCGH showed a heterogeneous copy-number pattern. We identified 133 CNVs, 18 them involved the most frequent changes already known or not yet related to ALL (Table 3). Unlike previous studies, here, amplifications were more frequent than deletions, possibly due the small sample number and the presence of hyperdiploid cases. On the other hand, similar to antecedent studies $[4,8,9]$, the more frequently altered genes were related to cell cycle regulation (ETV6), tumor suppression $(C D K N 2 A / B)$, apoptosis regulation (BTG1) and others (Table 3 ).

In agreement with the literature, in our study deletions of $C D K N 2 A / B$ were associated with positive cases for TCF3$P B X 1$ or $B C R-A B L 1$. $C D K N 2 A / B$ are tumor suppressor genes acting in cell growth regulation and apoptosis [10]. The deletion of these genes are associated with poor prognosis, high white blood cell count and older age at diagnosis and $B C R-A B L 1$ or TCF3-PBX1 translocations [11-13]; all characteristics found in our study group.

The aCGH study also identified for the first-time recurrent alterations of DMBT1, KIAA0125 and PRDM16 in ALL (Table 3). These genes were verified by qPCR in a larger sample number.

High amplification frequencies observed in aCGH was confirmed by qPCR just for KIAA0125. For the DMBT1 and PRDM16 deletions were prevalent in $\mathrm{qPCR}$ assays. This divergence is probably due to differences in sample size and by the presence of trisomy of chromosomes 1 and 10 in cases with copy number variation in PRDM16

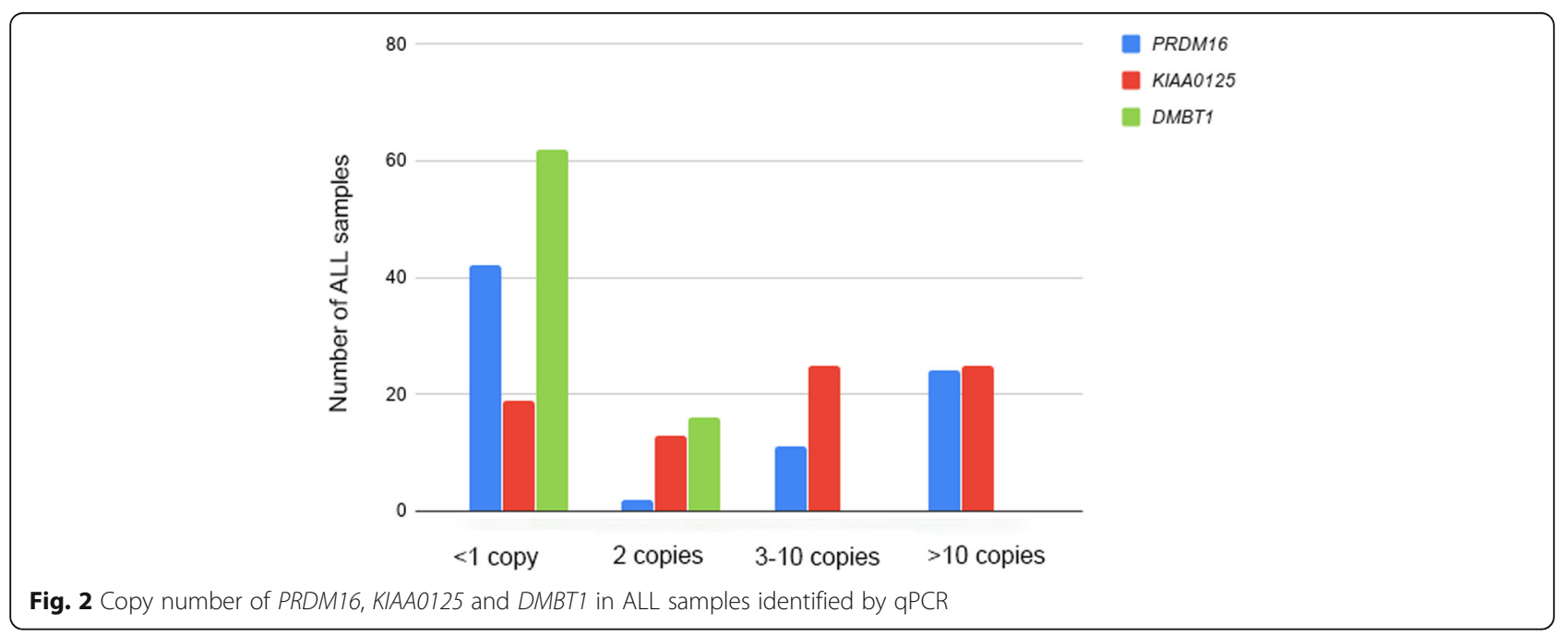


Table 4 Frequency of alterations according to characteristics of patients

\begin{tabular}{|c|c|c|c|c|c|c|}
\hline & DMBT1 d & & KIAA0125 & & PRDM16 de & \\
\hline & Present & Ausent & Present & Absent & Present & Absent \\
\hline $\mathrm{NCl}-\mathrm{HR}$ & 16 & 14 & 19 & 11 & 41 & 13 \\
\hline $\mathrm{NCl}-\mathrm{SR}$ & 46 & 8 & 31 & 23 & 1 & 29 \\
\hline$p$-value & $0.0036^{*}$ & & 0.6483 & & $p<0.001^{*}$ & \\
\hline$\leq 1$ years & 5 & 2 & 4 & 3 & 3 & 4 \\
\hline$>1$ to $\leq 10$ years & 44 & 10 & 34 & 20 & 26 & 28 \\
\hline$>10$ years & 13 & 10 & 12 & 11 & 13 & 10 \\
\hline$p$-value $1^{1}$ & 0.6131 & & 0.9994 & & 1 & \\
\hline$p$-value $2^{2}$ & 0.6693 & & 1 & & 0.6746 & \\
\hline$p$-value $3^{3}$ & $0.0433^{*}$ & & 0.4497 & & 0.6200 & \\
\hline WBC > 50 & 16 & 5 & 16 & 5 & 8 & 13 \\
\hline$W B C \leq 50$ & 46 & 17 & 34 & 29 & 34 & 29 \\
\hline$p$-value & 1 & & 0.0802 & & 0.4568 & \\
\hline Leucopenia & 5 & 0 & 5 & 0 & 0 & 5 \\
\hline Leucocytosis & 54 & 18 & 40 & 32 & 37 & 35 \\
\hline$p$-value & 0.3336 & & 0.0720 & & 0.0554 & \\
\hline Male & 38 & 11 & 31 & 18 & 21 & 28 \\
\hline Female & 24 & 11 & 19 & 16 & 21 & 14 \\
\hline$p$-value & 0.4515 & & 0.5002 & & 0.1839 & \\
\hline
\end{tabular}

NCI-HR NCl-High risk; NCI-SR NCI Standard risk; WBC White blood count. ${ }^{1} \leq 1$ years versus $>1$ to $\leq 10$ years; ${ }^{2} \leq 1$ years versus $>10$ years; ${ }^{3}>1$ to $\leq 10$ years versus $>10$ years. *Significant difference between groups with and without aberrations, $p \leq 0.05$, Fisher's exact test

Table 5 Frequency of alterations according to cytogenetic subgroups

\begin{tabular}{|c|c|c|c|c|c|c|}
\hline & \multicolumn{2}{|c|}{ DMBT1 deletion } & \multicolumn{2}{|c|}{ KIAA0125 amplification } & \multicolumn{2}{|c|}{ PRDM16 deletion } \\
\hline & Present & Ausent & Present & Absent & Present & Absent \\
\hline$B C R-A B L 1$ & 9 & 0 & 9 & 0 & 1 & 8 \\
\hline Absence & 53 & 22 & 41 & 34 & 41 & 34 \\
\hline$p$-value & 0.1036 & & $0.0032^{*}$ & & $0.0294^{*}$ & \\
\hline ETV6-RUNX1 & 7 & 0 & 7 & 0 & 0 & 7 \\
\hline Absence & 55 & 22 & 43 & 34 & 42 & 35 \\
\hline$p$-value & 0.1817 & & $0.0381^{*}$ & & $0.0119^{*}$ & \\
\hline$M L L-A F 4$ & 5 & 0 & 4 & 1 & 1 & 4 \\
\hline Absence & 57 & 22 & 46 & 33 & 41 & 38 \\
\hline$p$-value & 0.3195 & & 0.6438 & & 0.3597 & \\
\hline TCF3-PBX1 & 14 & 1 & 14 & 1 & 1 & 14 \\
\hline Absence & 48 & 21 & 36 & 33 & 41 & 28 \\
\hline$p$-value & 0.0625 & & $0.00031^{*}$ & & $0.0003^{*}$ & \\
\hline SIL-TALI & 3 & 0 & 3 & 0 & & \\
\hline Absence & 59 & 22 & 47 & 34 & 0 & 3 \\
\hline \multirow[t]{2}{*}{ p-value } & 0.5634 & & 0.2685 & & 42 & 39 \\
\hline & & & & & 0.2410 & \\
\hline$C T+$ & 38 & 1 & 37 & 2 & 3 & 36 \\
\hline CT- & 24 & 21 & 13 & 32 & 39 & 6 \\
\hline p-value & $p<0.001^{*}$ & & $p<0.001^{*}$ & & $p<0.001^{*}$ & \\
\hline
\end{tabular}


and DMBT1, respectively. But new significant associations were observed for the three genes.

The high frequency of DMBT1 deletions observed here support aCGH results. DMBT1 encoding protein belongs to the scavenger receptor cysteine rich (SRCR) super family involved in mucosal immune defense, epithelial differentiation and tumor suppression $[14,15]$. Many studies have showed that DMBT1 deletion or inactivation lead to tumorigenesis by regulating infiltration and metastasis of tumor cells [16]. Altered expression in certain stages of carcinogenesis was identified in different tumor types [17-19]. We found DMBT1 deletion associated with standard risk and $\mathrm{CT}+$ cases. It is possible that $D M B T 1$ deletion have a more specific function in development of ALL cases without a high risk chromosomal abnormality (which are mostly classified as standard risk), since only $14 \%$ of $\mathrm{CT}+$ cases have high risk biomarker (BCR-ABL1 or $M L L-A F 4)$. Thus, DMBT1 loss collaborate as a secondary event in the progression of disease in CT+ patients, since it is know that chromosomal translocations are primary aberrations [13]. Although $D M B T 1$ absence is considered a malignancy marker in many epithelial cancers, we reported for the first time $D M B T 1$ deletion in ALL and we suggest that DMBT1 may be also involved in hematologic malignancies development.

LncRNAs are involved in gene expression at epigenetic, transcriptional and post-transcriptional level and are considered a strong promise as a biomarker and therapeutic target [20]. In this study, we found that KIAA0125 amplifications were more common in CT+ patients while in CT- cases, deletions were more prevalent. Recurrent KIAA0125 amplifications were statistically associated with $\mathrm{CT}+$ cases. $\mathrm{CNV}$ or abnormal expression of KIAA0125 were observed in many tumor types [21-26]. Several recent studies in lncRNAs have shown that they have a critical role in different cancers acting as an oncogene or suppressor, in this sense, the role of KIAA0125 in carcinogenesis may be cell-type dependent [27]. In colon cancer development, KIAA0125 may contribute via the regulation of $B C L 2$ expression by sponging hsa-miR-29b-3p or regulating PI3K-Akt signaling [28]. In addition, Forero-Castro et al. [4] identified losses on 14q32.33 (where KIAA0125 is located) related to overall survival of children ALL with leukocytosis. In $14 \mathrm{q} 32$ there are miRNA clusters that may influence the genes expression levels involved in lymphoid B-cell transformation and differentiation, suggesting that $14 \mathrm{q} 32$ losses could be used as a diagnostic marker [4, 29]. Hornung R. et al. (2018) have recently shown that KIAA0125 could play a mediating role in the influence $R U N X 1$ gene fusions have on survival of LMA [30].

It is also presumable that KIAA0125 may act as miRNA sponges regulates mRNAs expression levels also in ALL, however the exact mechanism of action and possible target genes need to be further investigated. These findings along with our data leading to the assumption that KIAA0125 plays important role in development of leukemia and reinforce previous studies that suggested that lncRNAs may be utilized as diagnostic and prognostic markers in leukemia [20].

PRDM16 is characterized by the combination of a conserved N-terminal PR domain and a variable number of zinc fingers [31], it encodes a SMAD binding protein that may repress SMAD-mediated transcription, also functions as a modulator of TGF-beta signaling and exhibit methyltransferase activity [32,33]. PRDM16 is involved in various biological processes including maintenance of brown adipocytes and hematopoiesis [34, 35]. Two main PRDM16 isoforms are the full-length and the PR-lacking generated by alternative splicing or alternative use of different promoters [36, 37]. Notably, PRDM proteins sometimes exert opposing effects on tumor development [38, 39].

In the present study most cases have PRMD16 deletions (50\%), however in $90 \%$ of CT + patients this gene is highly amplified (21 samples with $>10$ copies) and significantly related to presence of gene fusions. Overexpression of PRDM16 in AML is associated with worse overall survival $[39,40]$ and is considered a risk factor for primary induction failure [41]. In addition it is associated with other gene fusions not investigated here [42]. Hu et al. [43] reported that PRDM16 transforming megakaryocyte-erythroid progenitors into myeloid leukemia stem cells. In another study, PRDM16 knockdown induced cell proliferation in rhabdoid tumor cells [44], suggesting that PRDM16 may be an oncogene in leukemia development, although in other tumor types PRDM16 has a controversial role $[45,46]$. Thus, the role of PRDM16 in cancer biology has been poorly studied and remains to be fully elucidated.

A limitation of this study was the small sample size. However, this is one of the few studies from the northern region of Brazil with genomic analysis in leukemia. This region has a large territorial extension, which makes the diagnosis of cancer a challenge due to its financial viability and the difficult access to geographically isolated regions of cancer treatment centers [47].

In conclusion, this study reinforces that aCGH it is a powerful tool for to identify regions of copy number variations in childhood ALL patients and to identify new genes associated to leukemia. Through this technique, we identified recurrent alterations in genes DMBT1, KIAA0125 and PRDM16; these alterations were verified by $\mathrm{qPCR}$ and confirmed the possible involvement of these genes in the development of leukemia, especially in ALL. DMBT1 probably is also a tumor suppressor in leukemia and is associated with standard risk and cases with gene fusions. Although both have a paradoxical behavior in tumorigenesis our data indicates that KIAA0125 and PRDM16 may act as oncogene, once 
amplifications in these two genes were related to gene fusions and leukocytosis, respectively. The combination of two molecular cytogenetics techniques has identified three genes that may be targets for further biological analysis of acute lymphoblastic leukemia.

\section{Abbreviations}

aCGH: Array Comparative Genomic Hybridization; ALL: Acute lymphoblastic leukemia; CNV: Copy Number Variation; CT+: Chromosome translocation positive; CT-: Chromosome translocation negative; HR: High Risk; NCl: National Cancer Institute; qPCR: quantitative Polymerase Chain Reaction; RT-PCR: Reverse Transcription Polymerase Chain Reaction; SR: Standard Risk; WBC: White Blood Count

\section{Acknowledgements}

We acknowledge all patients who participated in this study, Federa University of Pará, Evandro Chagas Institute for technical support and Coordination for Enhancement of Higher Education Personnel (CAPES) for fellowship support (Code 001).

\section{Authors' contributions}

JG, FM and MS performed the experiments. AK, EO, NS and BK participated in coordination and helped to draft the manuscript. AW and LP were responsible for sample collection. All authors read and approved the final manuscript.

\section{Funding}

This work was partially supported by the National Counsel of Technological and Scientific Development (CNPq), grant $n^{\circ}$ 460185/2014-4 and Amazon Foundation for Research Support (FAPESPA), grant n PPSUS/2013.

\section{Availability of data and materials}

The data will not be shared because some analyses of another genes study by aCGH are still being analyzed together with other data and have not yet been published.

\section{Ethics approval and consent to participate}

Octávio Lobo Children's Cancer Hospital ethics committee approved this study (CAAE: 00905812.1.0000.00.18). Written consent forms were obtained from all parents of patients and enabled the collection of biological samples and publication of results.

\section{Consent for publication}

Consent forms from the parents of patients were obtained to publish and to report individual data.

\section{Competing interests}

The authors declared that they have no conflict of interest.

\section{Author details}

${ }^{1}$ Oncology Research Center, Federal University of Pará, Belém, Brazil. ${ }^{2}$ Cell culture and Cytogenetic Laboratory, Evandro Chagas Institute, Ananindeua, Brazil. ${ }^{3}$ Octávio Lobo Children's Cancer Hospital, Belém, Brazil.

Received: 16 January 2020 Accepted: 8 June 2020

Published online: 26 June 2020

\section{References}

1. Scheurer ME, Bondy ML, Gourney JG. Epidemiology of childhood cancer. In: Pizzo PA, Poplack DG, editors. Principles and practice of pediatric oncology. Pennsylvania: Williams and Wilkins; 2011. p. 2-16.

2. INCA - Instituto Nacional do Câncer. Estimativa 2020 - Incidência de câncer no Brasil. http://www.inca.gov.br. Acessed 17 fev 2020.

3. Bacher U, Kohlmann A, Haferlach T. Gene expression profiling for diagnosis and therapy in acute leukaemia and other haematologic malignancies. Cancer Treat Rev. 2010. https://doi.org/10.1016/j.ctrv.2010.05.002.

4. Forero-Castro M, Robledo C, Benito R, Abáigar M, África Martín A, Arefi M, et al. Genome-wide DNA copy number analysis of acute lymphoblastic leukemia identifies new genetic markers associated with clinical outcome. PLoS One. 2016. https://doi.org/10.1371/journal.pone.0148972.
5. Hamadeh L, Enshaei A, Schwab C, Alonso CN, Attarbaschi A, Barbany G, et al. Validation of the United Kingdom copy-number alteration classifier in 3239 children with B-cell precursor ALL. Blood Adv. 2019. https://doi.org/10. 1182/bloodadvances.2018025718.

6. Graziano F, Galluccio N, Lorenzini P, Ruzzo A, Canestrari E, D'Emidio S, et al. Genetic activation ofthe MET pathway and prognosis of patients with highrisk, radicallyresected gastric cancer. J Clin Oncol. 2011. https://doi.org/10. 1200/JCO.2011.36.7706.

7. Ayres M, Ayres JR, Ayres DL, Santos AAS. BioEstat 5.0: statistical applications in the biological and medical sciences. Belém: CNPq; 2007.

8. Bungaro S, Dell'Orto MC, Zangrando A, Basso D, Gorletta T, Lo Nigro L, et al. Integration of genomic and gene expression data of childhood ALL without known aberrations identifies subgroups with specific genetic hallmarks. Genes Chromosomes Cancer. 2009. https://doi.org/10.1002/gcc.20616.

9. Dirse V, Bertasiute A, Gineikiene E, Zvirblis T, Dambrauskiene R, Gerbutavicius R, et al. A population-based single nucleotide polymorphism array analysis of genomic aberrations in younger adult acute lymphoblastic leukemia patients. Genes Chromosomes Cancer. 2015. https://doi.org/10. 1002/gcc.22246

10. Kim WY, Sharpless NE. The regulation of INK4/ARF in cancer and aging. Cell. 2006:127:265-75.

11. Usvasalo A, Savola S, Räty R, Vettenrantaa K, Harila-Saarid A, Koistinene P, et al. CDKN2A deletions in acute lymphoblastic leukemia of adolescents and young adults: an array CGH study. Leuk Res. 2008. https://doi.org/10.1016/j. leukres.2008.01.014

12. Schwab CJ, Chilton L, Morrison H, Jones L, Al-Shehhi H, Erhorn A, et al. Genes commonly deleted in childhood B-cell precursor acute lymphoblastic leukemia: association with cytogenetics and clinical features. Haematologica. 2013. https://doi.org/10.3324/haematol.2013.085175.

13. Moorman AV. Haematologica. New and emerging prognostic and predictive genetic biomarkers in B-cell precursor acute lymphoblastic leukemia. Haematologica. 2016. https://doi.org/10.3324/haematol.2015. 141101.

14. Mollenhauer J, Herbertz S, Holmskov U, Tolnay M, Krebs I, Merlo A, et al. DMBT1 encodes a protein involved in the immune defense and in epithelial differentiation and is highly unstable in cancer. Cancer Res. 2000;60:1704-10.

15. Singh N, Gupta DK, Sharma S, Sahu DK, Mishra A, Yadav DK, et al. Singlenucleotide and copy-number variance related to severity of hypospadias. Pediatr Surg Int. 2018. https://doi.org/10.1007/s00383-018-4330-5.

16. Takeshita H, Sato M, Shiwaku HO, Semba S, Sakurada A, Hoshi M, et al. Expression of the DMBT1 gene is frequently suppressed in human lung cancer. Jpn J Cancer Res. 1999:90(9):903-8.

17. Cheng J, Greshoc J, Shi L, Zheng S, Menius A, Lee K. Good practice guidelines for biomarker discovery from array data: A case study for breast cancer prognosis. BMC Syst Bio. 2013. https://doi.org/10.1186/1752-0509-7-S4-S2.

18. Muller $\mathrm{H}$, Renner M, Helmke BM, Mollenhauer J, Felderhoff-Muser U. Elevated DMBT1 levels in neonatal gastrointestinal diseases. Histochem Cell Biol. 2016. https://doi.org/10.1007/s00418-015-1381-8.

19. Muller H, Weiss C, Renner M, Felderhoff-Muser U, Mollenhauer J. DMBT1 promotes basal and meconium-induced nitric oxide production in human lung epithelial cells in vitro. HistochemCellBio. 2017. https://doi.org/10.1007/ s00418-016-14939.

20. Cruz-Miranda GM, Hidalgo-Miranda A, Bárcenas-López DA, Núñez-Enríquez JC, Ramírez-Bello J, Mejía-Aranguré JM, et al. Long non-coding RNA and acute leukemia. Int J Mol Sci. 2019. https://doi.org/10.3390/ijms20030735.

21. Seabra AD, Araújo TM, Mello Junior FA, Di Felipe Ávila Alcântara D, De Barros AP, De Assumpção PP, et al. High-density array comparative genomic hybridization detects novel copy number alterations in gastric adenocarcinoma. Anticancer Res. 2014;34(11):6405-15.

22. Chiu CG, Nakamura Y, Chong KK, Huang SK, Kawas NP, Triche T, et al. Genome-wide characterization of circulating tumor cells identifies novel prognostic genomic alterations in systemic melanoma metastasis. Clin Chem. 2014. https://doi.org/10.1373/clinchem.2013.213611.

23. Singchat W, Hitakomate $E$, Rerkarmnuaychoke B, Suntronpong A, Fu B, Bodhisuwan W, et al. Genomic alteration in head and neck squamous cell carcinoma (HNSCC) cell lines inferred from karyotyping, molecular Cytogenetics, and Array comparative genomic hybridization. PLoS One. 2016. https://doi.org/10.1371/journal.pone.0160901.

24. Li L, Qiang L, Yufeng L, Zhang L, Wu Y. Long non-coding RNA expression profiles predict clinical phenotypes of seminoma and yolk sac tumor. RSC Adv. 2017. https://doi.org/10.1039/c7ra12131h. 
25. Diniz MG, França JA, Vilas-Boas FAS, de Souza FTA, Calin GA, Gomez RS, et al. The long noncoding RNA KIAA0125 is upregulated in ameloblastomas. Pathol Res Pract. 2019. https://doi.org/10.1016/j.prp.2018.12.030.

26. Yao K, Wang $\mathrm{Q}$, Jia J, Zhao H. A competing endogenous RNA network identifies novel mRNA, miRNA and IncRNA markers for the prognosis of diabetic pancreatic cancer. Tumor Biol. 2017. https://doi.org/10.1177/ 1010428317707882.

27. Yang $Y$, Zhao Y, Hu N, Zhao J, Bai Y. IncRNA KIAA0125 functions as a tumor suppressor modulating growth and metastasis of colorectal cancer via Wnt/ B-catenin pathway. Cell Biol Int. 2019. https://doi.org/10.1002/cbin.11196.

28. Yang $Y$, Zhao $Y$, Zhang $W$, Bai $Y$. Whole transcriptome sequencing identifies crucial genes associated with colon cancer and elucidation of their possible mechanisms of action. Onco Targets Ther. 2019. https://doi.org/10.2147/ OTT.S195235.

29. Agueli C, Cammarata G, Salemi D, Dagnino L, Nicoletti R, La Rosa M, et al. $14 q 32 /$ miRNA clusters loss of heterozygosity in acute lymphoblastic leukemia is associated with up-regulation of BCL11a. Am J Hematol. 2010. https://doi.org/10.1002/ajh.21758.

30. Hornung R, Jurinovic V, Batcha AMN, Bamopoulos SA, Rothenberg-Thurley $M$, Amler $S$, et al. Mediation analysis reveals common mechanisms of RUNX1 point mutations and RUNX1/RUNX1T1 fusions influencing survival of patients with acute myeloid leukemia. Sci Rep. 2018. https://doi.org/10. 1038/s41598-018-29593-2.

31. Di Zazzo E, De Rosa C, Abbondanza C, Moncharmont B. PRDM proteins: molecular mechanisms in signal transduction and transcriptional regulation. Biology (Basel). 2013. https://doi.org/10.3390/biology2010107.

32. Warner DR, Greene RM, Pisano MM. PRDM16 in development and disease. Human Genet Embryol. 2014. https://doi.org/10.4172/2161-0436.1000121.

33. Mehrian-Shai R, Yalon M, Moshe I, Barshack I, Nass D, Jacob J, et al. Identification of genomic aberrations in hemangioblastoma by droplet digital PCR and SNP microarray highlights novel candidate genes and pathways for pathogenesis. BMC Genomics. 2016. https://doi.org/10.1186/ s12864-016-2370-6.

34. Yin H, Pasut A, Soleimani VD, Bentzinger CF, Antoun G, Thorn S, et al. MicroRNA-133 controls brown adipose determination in skeletal muscle satellite cells by targeting Prdm16. Cell Metab. 2013. https://doi.org/10.1016/ j.cmet.2013.01.004

35. Aguilo F, Avagyan S, Labar A. Prdm16 is a physiologic regulator of hematopoietic stem cells. Blood. 2011. https://doi.org/10.1182/blood-2010 08-300145.

36. Sorrentino A, Federico A, Rienzo M, Gazzerro P, Bifulco M, Ciccodicola A. PR/ SET domain family and Cancer: novel insights from the Cancer genome atlas. Int J Mol Sci. 2018. https://doi.org/10.3390/ijms19103250.

37. Mzoughi S, Tan YX, Low D, Guccione E. The role of PRDMs in cancer: one family, two sides. Curr Opin Genet Dev. 2016. https://doi.org/10.1016/j.gde. 2016.03.009.

38. Fog CK, Galli GG, Lund AH. PRDM proteins: important players in differentiation and disease. BioEssays. 2012. https://doi.org/10.1002/bies. 201100107.

39. Yamato G, Yamaguchi H, Handa H, Shiba N, Kawamura M, Wakita S, et al. Clinical features and prognostic impact of PRDM16 expression in adult acute myeloid leukemia. Genes Chromosomes Cancer. 2017. https://doi.org/ 10.1002/gcc.22483.

40. Duhoux FP, Ameye G, Montano-Almendras CP, Bahloula K, Mozziconacci MJ, Laibe S, et al. PRDM16 [1p36] translocations define a distinct entity of myeloid malignancies with poor prognosis but may also occur in lymphoid malignancies. Br J Haematol. 2012. https://doi.org/10.1111/j.1365-2141.2011. 08918.x.

41. Miyamura T, Moritake H, Nakayama H, Tanaka S, Tomizawa D, Shiba N, et al. Clinical and biological features of paediatric acute myeloid leukaemia (AML) with primary induction failure in the Japanese PaediatricLeukaemia/ lymphoma study group AML-05 study. Br J Haematol. 2019. https://doi.org/ 10.1111/bjh.15799

42. Shiba N, Ohki K, Kobayashi T, Hara Y, Yamato G, Tanoshima R, et al. High PRDM16 expression identifies a prognostic subgroup of pediatric acute myeloid leukaemia correlated to FLT3-ITD, KMT2A-PTD, and NUP98-NSD1: the results of the Japanese Paediatric Leukaemia/lymphoma study group AML-05 trial. Br J Haematol. 2016. https://doi.org/10.1111/bjh.13869.

43. Hu T, Morita K, Hill MC, Jiang Y, Kitano A, Saito Y, et al. PRDM16s transforms megakaryocyte-erythroid progenitors into myeloid leukemia-initiating cells. Blood. 2019. https://doi.org/10.1182/blood.2018888255.
44. Tegeder I, Thiel K, Erkek S, Johann PD, Berlandi J, Thatikonda V, et al. Functional relevance of genes predicted to be affected by epigenetic alterations in atypical teratoid/rhabdoid tumors. J Neuro-Oncol. 2019. https://doi.org/10.1007/s11060-018-03018-6.

45. Fei LR, Huang WJ, Wang Y, Lei L, Li ZH, Zheng YW, et al. PRDM16 functions as a suppressor of lung adenocarcinoma metastasis. J Exp Clin Cancer Res. 2019. https://doi.org/10.1186/s13046-019-1042-1.

46. Deng J, Kong W, Mou X, Wang S, Zeng W. Identifying novel candidate biomarkers of RCC based on WGCNA analysis. Per Med. 2018. https://doi. org/10.2217/pme-2017-0091.

47. Silva-Junior AL, Alves FS, Kerr MWA, Xabregas LA, Gama FM, Rodrigues MGA et al. Acute lymphoid and myeloid leukemia in a Brazilian Amazon population: epidemiology and predictors of comorbidity and deaths. PLoS One. 2019. https://doi.org/10.1371/journal.pone.0221518.

\section{Publisher's Note}

Springer Nature remains neutral with regard to jurisdictional claims in published maps and institutional affiliations.
Ready to submit your research? Choose BMC and benefit from:

- fast, convenient online submission

- thorough peer review by experienced researchers in your field

- rapid publication on acceptance

- support for research data, including large and complex data types

- gold Open Access which fosters wider collaboration and increased citations

- maximum visibility for your research: over $100 \mathrm{M}$ website views per year

At BMC, research is always in progress.

Learn more biomedcentral.com/submissions 